\title{
CONTRIBUIÇÕES DA EPISTEMOLOGIA BACHELARDIANA NO ESTUDO DA HISTÓRIA DA ÓPTICA
}

\section{Contributions from bachelardian epistemology in the study of the history of Optics}

\author{
Ana Carolina Staub de Melo ${ }^{1}$ \\ Luiz. O. Q. Peduzzi
}

\begin{abstract}
Resumo: O presente artigo explora um diálogo entre a história e a filosofia da ciência. Nesta perspectiva, apresenta uma articulação entre a história da óptica e as principais características da filosofia histórica de Gaston Bachelard, dando ênfase: aos períodos de rupturas e descontinuidades presentes no constante confronto entre o modelo corpuscular e ondulatório da luz; à permanente retificação do erro - e ao novo conceito de verdade presente na construção da concepção sobre a natureza da luz -; à noção de recorrência histórica articulada à análise dos estudos sobre reflexão e refração; ao uso do recurso analógico na estruturação da hipótese ondulatória da luz, proposta por Huygens; e à dialética racionalismo-empirismo no exemplo da natureza dual dos elétrons.
\end{abstract}

Palavras-chave: História da óptica. Epistemologia bachelardiana. História e Filosofia da ciência.

\begin{abstract}
The present article explores the interaction between History and the Philosophy of Science. In this way, it presents an articulation between the History of Optics and the main characteristics of Gaston Bachelard's historical philosophy. It emphasizes: firstly, the periods of rupture and discontinuities present in the confrontation between the light corpuscular and wave models; secondly, the permanent error rectification, in the sense that one knowledge abuts another, and the new concept of truth, present in the construction of the conception about the nature of light; thirdly, the notion of historical recurrence, articulated in the analysis of studies about reflection and refraction particularly Arquimedes' polemic of incandescent mirrors; fourthly, the use of analogical reasoning in the structuring of the light wave hypothesis proposed by Huygens; and finally, the rationalism-empiricism dialectics in the example of the dual nature of the electron.
\end{abstract}

Key words: History of optics. Bachelardian epistemology. History and the Philosophy of science.

\footnotetext{
${ }^{1}$ Doutoranda; Programa de Pós-Graduação em Educação Científica e Tecnológica, Universidade Federal de Santa Catarina (UFSC). Florianópolis, SC. < anacarolina2512@yahoo.com.br>

${ }^{2}$ Doutor em Educação; docente, departamento de Física; Programa de Pós-Graduação em Educação Científica e Tecnológica, Universidade Federal de Santa Catarina (UFSC). Florianópolis, SC. <peduzzi@fsc.ufsc.br>
}

\footnotetext{
${ }^{1}$ Av. Brigadeiro Silva Paes 199, apto T 01, bl. B, Campinas - São José, SC $88.101-250$
} 
Melo, A. C. S.; Peduzzi, L. O. Q.

\section{Introdução}

Em geral, o ensino de Física prioriza o produto final da ciência, encerrando, em uma visão simplificada e, por vezes, equivocada, a natureza e construção do conhecimento científico e a imagem do próprio cientista. Conforme evidenciam diversas pesquisas (MORAES, 2003; PEIXOTO e MARCONDES, 2003; SILVA et al., 2002; DELIZOICOV, 2002; GIL-PÉREZ et al., 2001; PEDUZZI, 2001; HARRES, 1999; BORGES, 1996), a idéia da observação neutra e objetiva - contrastando com a concepção de que a observação está impregnada de teoria; a convicção em uma história da ciência cumulativa e linear - opondo-se à perspectiva de rupturas e descontinuidades; e a imagem de um cientista simbolizando o gênio das freqüentes idéias iluminadoras, personagem das descobertas científicas, e negando a perspectiva humana que erra, falha, frustra-se, apaixona-se por sua pesquisa ilustram um amplo espectro de características da ciência presentes no ensino de ciências.

O artigo Para uma imagem não deformada do trabalho cientifico (GIL-PÉREZ et al., 2001), por exemplo, apresenta sete visões deformadas do trabalho científico presentes na concepção de professores de ciências, destacando-se: visão empirico-indutivista e ateórica; visão rígida (algoritmica, exata, infalivel, ...); visão abistórica e aproblemática; visão exclusivamente analítica; visão acumulativa de crescimento linear, visão individualista e elitista e visão socialmente neutra.

$\mathrm{Na}$ mesma perspectiva, Peixoto e Marcondes (2003) discutem visões equivocadas da ciência presentes nas interpretações de alunos inscritos em um programa especial de formação de professores de química para o Ensino Médio. De forma bastante similar aos estudos realizados nesse sentido em cenários diversos, os pesquisados apresentam concepções inadequadas da ciência, como a crença em um método científico absoluto, a neutralidade inerente à observação, o consenso em um contexto de mudança científica, as teorias científicas compreendidas como estanques e, portanto, definitivas.

Tendo em vista as pesquisas que enfatizam as interpretações equivocadas do trabalho científico presentes na visão de professores de ciências, Zimermann e Bertani (2003) sinalizam que a visão de ciência dos professores intervém em suas estratégias e práticas pedagógicas, repercutindo diretamente na formação e estruturação do pensamento do aluno. Assim, devese pensar melhor na formação de professores de ciências, para que não reproduzam em sala de aula concepções distorcidas sobre o tema.

A história e a filosofia da ciência podem contribuir para uma imagem mais crítica e humana da gênese e do desenvolvimento da ciência, desmistificando a atividade científica (CASTRO, 2004; NASCIMENTO, 2004; FREIRE, 2000; MEDEIROS e BEZERRA, 2000; LOMBARDI, 1997; VANNUCCHI, 1996; MATTHEWS, 1995; ZANETIC, 1989; KNELLER, 1987). Conforme Peduzzi (2004, p. 7) "a filosofia da ciência ilumina a história da ciência. Sem ela, esta história é acrítica, enciclopédica, dogmática, linear, sem tropeços, sem idas e vindas, 'racionalmente racional"'.

Staub e Peduzzi (2003a, 2003b) destacam várias possibilidades e contribuições da filosofia da ciência no estudo da dimensão histórica do conhecimento, discorrendo sobre exemplos específicos da História da Física para ilustrar a riqueza dessas discussões. Entre elas, pode-se enfatizar: diferentes posicionamentos sobre a influência de elementos não ortodoxos na obra de Newton - um contraste entre a imagem de um Newton estritamente racional e outro, enigmático, que aprecia e estuda arduamente a alquimia e a teologia (THUILLIER, 
1994); algumas interpretações sobre o trabalho de Galileu, personagem bastante polêmico na História da Física (DRAKE, 1981; KOYRÉ, 1986; FEYERABEND, 1977); a questão da acidentalidade na experiência de Oersted (MARTINS, 1986; BASSALO, 1987); o problema da suplantação do sistema ptolomaico pelo copernicano (LAKATOS, 1998; KUHN, 1987; KOYRÉ, 1979); a possível inspiração metafísica em Copérnico quando, na abertura do De revolutionibus, comenta o porquê de situar o sol em uma posição central no universo (KOYRÉ, 1979; LANG, 2002).

Este artigo desenvolve uma análise da evolução das teorias físicas sobre a natureza da luz, com base na filosofia histórica de Bachelard, epistemólogo que concebe a construção do conhecimento na perspectiva de rupturas e descontinuidades (BACHELARD, 2001; 1999; 1979a). A primazia conferida ao erro, como positivo e inerente ao ato de conhecer, explicita as características transformadoras de sua filosofia, que interpreta, no âmbito da cultura e do conhecimento, não mais a verdade, mas as verdades múltiplas, históricas, provisórias, a natureza efêmera do conhecimento articulada ao conceito de verdade (LOPES, 1996a, 1996b). A filosofia histórica de Bachelard desconstrói a visão de que a verdade se configura estanque e, por isso, definitiva e tangível. O perfil epistemológico de Bachelard (1979b) retrata esse pluralismo de idéias, associado aos conhecimentos, as distintas significações de um conceito ao longo da história da ciência e da história do próprio homem, que interpreta distintamente uma idéia ao longo de sua existência. O eterno recomeçar exprime a marca dos pressupostos de Bachelard. Portanto, até uma pergunta como o que é ciência? resulta sem sentido, pois, com base nos racionalismos setoriais, os critérios de cientificidade são determinados coletiva e setorialmente pelas ciências e, assim, são variáveis no tempo (BACHELARD, 1990).

O pensamento bachelardiano tem sido usado com sucesso como referência por diversas pesquisas no campo da educação em ciências. Mortimer (2000), por exemplo, utiliza a noção de perfil epistemológico como referencial para a construção de estratégias para o ensino do atomismo em nível elementar. Tendo em vista que as pessoas podem apresentar diferentes formas de interpretar o mundo à sua volta, dialogando com várias referências para produzir seu próprio conhecimento, o autor delineia um perfil conceitual para o atomismo com base em estudos desenvolvidos sobre as concepções de estudantes relativas ao átomo e aos estados físicos da matéria.

Silveira (2003) analisa o conceito de substância no ensino de química à luz da concepção de obstáculo e perfil epistemológico na filosofia histórica de Bachelard. Examina seis coleções didáticas de $5^{a}$ a $8^{a}$ séries do Ensino Fundamental, sinalizadas pelo PNLD/2002 (Plano Nacional do Livro Didático). Em parte significativa dos livros analisados, o estudo evidencia a presença de obstáculos substancialistas e realistas em virtude, principalmente, da não consideração das distintas interpretações presentes na evolução histórica do conceito de substância. De acordo com esse autor, a primazia conferida à classificação das substâncias, estudadas sem definição precisa e contextualizada, enfatiza o produto do conhecimento, ressaltando um conceito ahistórico e aproblemático, que repercute em um entendimento simplificado e ingênuo do tema abordado. Pensar o perfil epistemológico do conceito de substância, conforme defende, em princípio, possibilitaria uma compreensão contextual e rica do conhecimento.

As próximas seções procuram mostrar mais uma contribuição da epistemologia de Bachelard ao ensino de ciências, em particular, de Física. 
Melo, A. C. S.; Peduzzi, L. O. Q.

\section{A epistemologia bachelardiana e a história da óptica}

Em busca de uma articulação entre história e filosofia da ciência, procura-se estabelecer, neste trabalho, uma ponte entre conceitos da epistemologia bachelardiana e a história da óptica. O quadro a seguir (apresentado no XVI Simpósio Nacional do Ensino de Física) sintetiza a possibilidade desse diálogo (STAUB e PEDUZZI, 2005):

\begin{tabular}{|c|c|c|}
\hline $\begin{array}{l}\text { Dimensão filosófica } \\
\text { Epistemologia Bachelardiana }\end{array}$ & & $\begin{array}{l}\text { Dimensão histórica } \\
\text { História da Óptica }\end{array}$ \\
\hline $\begin{array}{l}\text { Rupturas e descontinuidades } \\
\text { (o erro e a verdade) }\end{array}$ & $\stackrel{\text { articulação }}{\longrightarrow}$ & $\begin{array}{l}\text { O confronto entre a concepção corpuscular e ondulatória } \\
\text { da luz ao longo da história da óptica }\end{array}$ \\
\hline Recorrência histórica & articulação & $\begin{array}{l}\text { Uma análise dos estudos sobre reflexão e refração: a } \\
\text { polêmica acerca dos espelhos ardentes de Arquimedes }\end{array}$ \\
\hline Analogias e metáforas & articulação & $\begin{array}{l}\text { O uso do recurso analógico na estruturação da hipótese } \\
\text { ondulatória da luz proposta por Huygens }\end{array}$ \\
\hline $\begin{array}{l}\text { Dialética } \\
\text { racionalismo-empirismo }\end{array}$ & articulação & O exemplo da natureza dual dos elétrons \\
\hline
\end{tabular}

As próximas seções encerram uma discussão sobre a história da natureza da luz vinculada a conceitos da epistemologia bachelardiana, destacando-se: os períodos de rupturas e descontinuidades presentes no constante confronto entre o modelo corpuscular e ondulatório da luz; à permanente retificação do erro, no sentido de que um conhecimento se dá contra outro; ao novo conceito de verdade presente na construção da concepção sobre a natureza da luz; à noção de recorrência histórica articulada à análise dos estudos sobre reflexão e refração, particularmente a polêmica dos espelhos incandescentes de Arquimedes; ao uso do recurso analógico na estruturação da hipótese ondulatória da luz proposta por Huygens; e à dialética racionalismo-empirismo no exemplo da natureza dual dos elétrons.

\section{Rupturas e descontinuidades na evolução da óptica}

\section{Do mundo físico grego ao século XVII: sobre os mecanismos da visão e a natureza da luz}

No mundo grego (século III a.C.), berço da ciência ocidental, encontram-se duas teorias físicas de natureza distinta: o atomismo e a física do contínuo. As concepções dos estóicos sobre a propagação da luz em um meio, o pneuma, suscitam um confronto com os 
atomistas, que sustentam o caráter descontínuo da matéria (SAMBURSKY, 1990). Articular a idéia da filosofia bachelardiana de rupturas e descontinuidades ao estudo das raízes histórias da óptica possibilita compreender as distintas premissas teóricas que dirigiam o pensamento dos filósofos gregos acerca do mecanismo da visão e do que é a luz, entre outras coisas.

A física do contínuo é uma criação original dos estóicos: de Zenon, Crisipo e Posidônio, suas maiores expressões. A pedra angular da física estóica é a natureza contínua da matéria e da propagação dos fenômenos físicos.

Para os estóicos, há um elemento ativo, combinação de ar e fogo, responsável por unir e encadear em um todo único e dinâmico o cosmos. A esse princípio regulador de todos os fenômenos chamou-se pneuma, termo grego que significa 'espírito' ou 'alento'. Além de impedir a existência do vazio dos atomistas, no mundo sensível, o pneuma ensejava a coesão e conexão das coisas, devido a suas qualidades tensoras. Como destaca Abrantes (1998, p. 46):

A rigor, os estóicos admitem o vazio fora do mundo, já que concebiam o mundo na qualidade de conjunto de corpos - como finito e envolto por um vazio que se estende indefinidamente... 'Neste contexto' o pneuma possui diversas funções na concepção estóica da natureza. Ele constitui uma força integradora e dinamizadora do cosmos. Sem essa ação do pneuma, o mundo tenderia a se dispersar pelo vazio que o envolve, e os corpos, individualmente, tampouco manteriam coesão.

No âmbito dos fenômenos biológicos, os motivos para a aceitação do pneuma mostravam-se igualmente 'óbvios', dado o reconhecimento de que os processos térmicos eram indissociáveis da vida orgânica, do crescimento e desenvolvimento dos seres vivos. Conforme Sambursky (1990, p. 158) "as funções dinâmicas do fogo e do ar foram estendidas para abarcar todos os fenômenos naturais". A suposição dos estóicos era que os seres vivos estavam impregnados desse princípio vivo, dinâmico e 'regulador' do universo. O percentual variável de fogo e de ar em sua composição propiciava sua associação à diversidade dos acontecimentos nos reinos orgânico e inorgânico, ao mundo físico em geral.

Por outro lado, a concepção da matéria composta por partículas indivisíveis, imutáveis, duras, indestrutíveis, infinitas em número e inacessíveis aos olhos humanos, articulada à idéia da ausência de matéria, ou seja, existência do vazio, constitui o núcleo duro das premissas teóricas dos atomistas.

Sob a ação de forças da mais diversa natureza a matéria se desagrega, se dissolve, se despedaça, mas os seus elementos básicos permanecem incólumes, pois nada pode voltar ao nada. Como nada pode surgir do nada, são novas associações desses 'germes' que vão constituir novos corpos. É desse modo que a natureza opera, refazendo os corpos uns a partir dos outros. (PEDUZZI, 2005)

O átomo grego é eterno. Esses corpúsculos diferem em tamanho, em forma, em movimentos e arranjos geométricos. A diversidade de todas as coisas é explicada por essas diferenças. A rigidez de um objeto, por exemplo, deve-se ao maior ou menor grau de compactamento dos átomos que o constituem. Tal como os estóicos, os atomistas dirigem seu pensamento para o sentido de abarcar explicações sobre todos os fenômenos, inclusive os relativos à vida.

Em O mundo físico dos gregos, Sambursky (1990) contrasta as concepções dos atomistas 
e dos estóicos sobre a natureza e a propagação da luz. Para os atomistas, a luz é composta por átomos sutis, arredondados e velozes. A visão é possível em virtude de um fluxo de partículas emanado do objeto, que é assimilado pelos olhos. Já para os estóicos a explicação da visão é mais complexa:

Supostamente, tem origem na alma do observador uma luz, que chega ao olho como uma onda, através do pneuma existente no corpo humano. Ao deixar o olho, esta luz perturba o ar, que se expande na forma de um cone, até encontrar o objeto visado. Este é percebido pelo sujeito por meio de uma nova propagação ondulatória, através da agitação do ar, captada pelo olho e transmitida a sua alma, pelo pneuma. (SAMBURSKY, 1990, p. 164)

As raízes históricas do conhecimento grego acerca da formação de imagens e da natureza da luz geram um importante questionamento: é possível considerar as concepções estóica e atomista precursoras ${ }^{3}$, respectivamente, das teorias corpuscular (Newton) e ondulatória (Huygens) da luz, desenvolvidas no século XVII? Em uma perspectiva mais geral: um conhecimento mais recente pode ser considerado a forma adulta de concepções embrionárias existentes em épocas passadas (e, neste caso, seria inevitável uma concepção de crescimento gradual, linear e contínuo da ciência)?

Em princípio, parece simples entender as idéias físicas do mundo grego como os embriões teóricos do modelo ondulatório (Huygens) e corpuscular (Newton) da luz, dentro de uma concepção de progresso cumulativo. No entanto, Bachelard critica de forma contundente a imagem de um progresso contínuo do conhecimento científico, acentuando o caráter descontínuo da razão.

Como se pode evidenciar, as explicações de atomistas e estóicos sobre a visão - e o que vem a ser a luz - estavam fundadas em distintas visões de mundo. A partir do século XVII, a polêmica acerca da natureza da luz, entre os modelos corpuscular e ondulatório, repete-se, mas agora vinculada à realidade de outro contexto histórico ${ }^{4}$, caracterizado por novas idéias sobre o universo e os métodos da ciência. Efetivamente, naquele século tem curso um processo de mudanças significativas na ciência (ABRANTES, 1998; HENRY, 1998).

Nessa perspectiva, Descartes e Fermat são protagonistas de novos conflitos sobre a luz e a visão. Para demonstrar a lei da refração, em 1637, partindo da teoria corpuscular,

\footnotetext{
${ }^{3}$ A idéia de precursor incorpora em sua essência a crença em um desenvolvimento cumulativo do conhecimento, sem respeitar o contexto histórico-cultural no qual nasce e se estrutura uma teoria. Contudo, cabe destacar que os cientistas não simbolizam gênios que, destituídos de toda e qualquer carga teórica, mantêm a imaginação livre, desconhecendo, inclusive, a história, com objetivo de acessar o secreto do mundo natural.

${ }^{4}$ Os séculos XVI e XVII foram cenário de modificações radicais nas imagens de natureza e de ciência herdadas da Antiguidade... Ocorreu, nesse período de dois séculos, não somente uma revolução astronômica - que substituiu o geocentrismo pelos heliocentrismo e, de modo mais geral, uma revolução cosmológica, que substituiu um mundo finito por um universo infinito -, mas, também, uma revolução na então chamada física terrestre. Essa última revolução, que culminou com a mecânica galilaico-newtoniana, pode ser vista como decorrência da revolução astronômica e cosmológica, já que a física de Aristóteles não pode ser compatibilizada com o heliocentrismo e com a concepção de universo infinito.
} 
Descartes infere que a velocidade da luz deveria ser maior em meios mais densos (mais refringentes). Já Fermat, em 1661, com base no 'postulado do tempo mínimo', chega a um resultado contrário: de que a luz em meios mais refringentes tem menor velocidade. A divergência entre as duas concepções teóricas, objetos de controvérsias, cresce com os trabalhos de Huygens (teoria em concordância com Fermat) e Newton (teoria de acordo com Descartes) e com as evidências experimentais concernentes aos fenômenos de difração (1665), interferência (1665) e polarização (1669) (BARTHEM, 2005).

$\mathrm{Na}$ Grécia Antiga, a tendência do pensamento era a da primazia às construções teóricas para explicar a totalidade dos fenômenos do mundo natural, apoiando as interpretações fundamentalmente na evidência sensível. Por outro lado, na ciência moderna a ascensão da matemática sobre as considerações e o exame da natureza, articulada à experimentação sistematizada, ilustra o nascimento de uma nova 'imagem de natureza'. Segundo Abrantes (1998, p. 54):

(...) a incorporação da experimentação sistemática ao elenco de métodos empregados na investigação científica.... exigiu uma mudança nas concepções de natureza que prevaleceram na Antiguidade. $\mathrm{O}$ recurso à experimentação talvez seja o traço mais freqüentemente apontado como característico das ciências naturais. O cientista não observa simplesmente a natureza, mas produz (e reproduz) fenômenos em condições artificiais, em que alguns aspectos ou variáveis do fenômeno são selecionados, e outros são eliminados ou controlados.

Conforme Lopes (1996a, p. 255), a filosofia tradicional da ciência interpreta a evolução histórica da cultura e do conhecimento a partir da imagem de um progresso contínuo. Essa crença difunde a imagem de que conceitos, idéias e teorias se desenvolvem como o desenrolar de um novelo, os conhecimentos somam-se de forma gradativa uns aos outros, sem respeitar seus distintos contextos de origem, e "as idéias atuais são entendidas como préexistentes de forma embrionária em épocas anteriores". Ainda segundo o autor:

Em síntese, os continuistas não analisam o pensamento filosófico inserido em sua cultura, com pressupostos e visões próprias de mundo, porque interpretam a cultura como um todo monolítico, história cumulativamente contada, na qual há formulações de infância e de vida adulta. Insistem em ver todo acontecimento do passado como uma preparação dos acontecimento do presente. (LOPES, 1996a, p. 256)

De acordo com esse pensamento, os saberes que constituem uma ciência, como a Física, por exemplo, refletem uma construção estabelecida sobre uma única racionalidade, e domínios teóricos de natureza distinta manifestam a existência de um fio condutor de influências ao longo da história.

Entretanto, os cenários em que se configuram as disputas entre estóicos e atomistas de um lado - e Descartes e Fermat - de outro - são muito diferentes. Com Bachelard (1999, 1990) pode se entender melhor isso. Não é demais ressaltar que a antiguidade clássica contempla ideais frontalmente dissonantes dos que constituem o contexto da ciência moderna: as concepções de mundo estão veiculadas a domínios de natureza distinta, agregados a pressu- 
Melo, A. C. S.; Peduzzi, L. O. Q.

postos radicalmente dicotômicos. As revolucionárias e expressivas mudanças ocorridas no século XVII, palco de um amplo movimento cultural relacionado ao nascimento da ciência moderna, desencadeiam alterações profundas na compreensão da natureza, organização social e prática científica.

\section{Rupturas e descontinuidades na evolução da óptica}

\section{Um breve percurso ao longo da história da óptica: de Newton a Einstein}

A primazia conferida pela epistemologia histórica de Bachelard (1975) ao permanente processo de reconstrução do saber científico traduz o aspecto descontinuista da razão. As oscilações entre a teoria corpuscular e a teoria ondulatória da luz, vivenciadas pela comunidade científica a partir do século XVII, ilustram que não existe um contínuo e linear entrelaçamento de idéias ao longo da história da óptica. Há freqüentes rupturas e descontinuidades, mudanças de visão, pressupostos e convicções teóricas em relação à luz (BARTHEM, 2005; ROCHA, 2002).

A concepção corpuscular newtoniana, apesar de rivalizar com a ondulatória proposta por Huygens (1678), predominou durante todo século XVIII. Elas contemplam conjecturas teóricas antagônicas quanto à velocidade da luz, resolvidas com as experiências de Fizeau (1850) e Foucault (1851), que corroboraram a hipótese ondulatória. No entanto, a maior aceitação da concepção ondulatória consolida-se anteriormente, com sua retomada por Young (1802) e, mais tarde, por Fresnel (ABRANTES, 1998).

A experiência da fenda dupla de Young, realizada em 1801 (fig.1), fragiliza a hipótese corpuscular da luz, embora não seja determinante para seu abandono. Contudo, as figuras de interferência luminosa obtidas em um anteparo e o comprimento de onda da luz medido pela experiência constituem fortes componentes para o ressurgimento da hipótese ondulatória da luz, que culmina com as experiências de Airy, Foucault, e Fizeau.

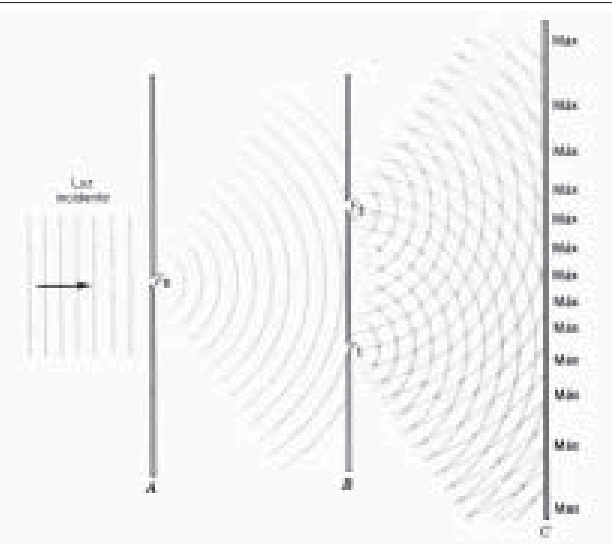

Figura 1. Na experiência de interferência de Young, a luz difratada em um orifício circular $F_{0}$ incide sobre os furos $F_{1}$ e $F_{2}$ na tela $B$. A luz difratada por esses dois furos superpõe-se sobre a tela $C$, produzindo uma figura de interferência. (HALLIDAY et al., 1996, p. 59). 
Young propõe a hipótese da transversalidade das ondas luminosas, tendo em vista as vibrações em uma corda, perpendiculares à direção de propagação. Contrapõe-se, assim, à perspectiva de Huygens, que admitia, por analogia com o som, que as vibrações da onda luminosa eram longitudinais, ocorrendo na mesma direção de propagação da onda. As experiências realizadas por Airy (1833), referentes ao fenômeno de interferência, e, fundamentalmente, as de Foulcault e Fizeau (1850), que mediram a velocidade da luz em meios mais densos que o ar, mostraram-se essenciais para corroborar as premissas teóricas de Huygens.

Para a teoria ondulatória, o efeito das cores em uma placa delgada após a incidência de um feixe de luz era conseqüência da interferência da luz refletida pela primeira e segunda superfície da placa. Segundo a teoria corpuscular, as cores produzidas resultavam da luz refletida somente pela segunda superfície. Assim, ao impedir a reflexão na primeira superfície, Airy confirma as previsões teóricas do modelo ondulatório (ROCHA, 2002).

O modelo ondulatório previa que, ao passar do ar para a água, a velocidade da luz deveria diminuir. Como ilustra a figura 2a, tendo em vista que o raio de luz refratado aproxima-se da normal, a previsão teórica era de que o comprimento da onda refratada fosse reduzido ao incidir sobre um meio mais denso. Como a freqüência é constante, a velocidade da luz deveria diminuir:

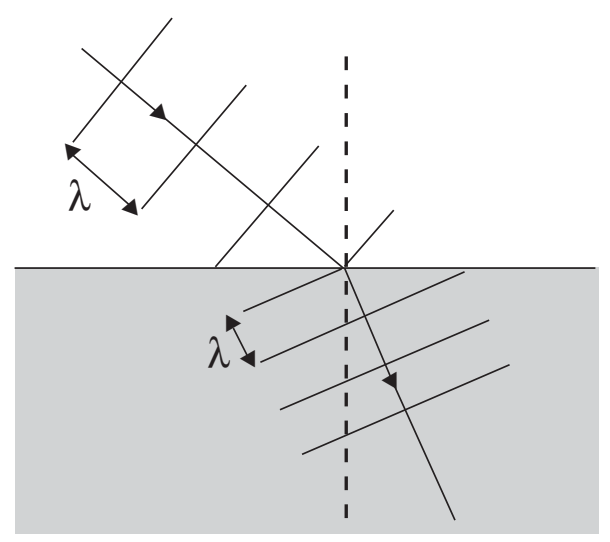

Figura 2a. O fenômeno da refração segundo a teoria ondulatória da luz (INEP, 2000).

Com pressupostos contrários, o modelo corpuscular previa que, ao passar do ar para a água, a velocidade da luz deveria aumentar. Como o raio de luz se aproxima da normal, na passagem da luz do ar para a água, a hipótese teórica sugeria que seria necessária a existência de uma força atuando no sentido de acelerar o corpúsculo para dentro da água, aumentando, por conseguinte, sua velocidade. A figura $2 \mathrm{~b}$ sintetiza essas premissas.

No entanto, a maior aceitação da teoria ondulatória não é definitiva, devido ao registro, por Hertz, do que viria a ser posteriormente conhecido como efeito fotoelétrico. O objetivo de Hertz era confirmar experimentalmente a previsão de Maxwell de que a luz é uma onda eletromagnética. $\mathrm{O}$ efeito fotoelétrico caracteriza mais uma ruptura na forma de pensar a natureza da luz. 


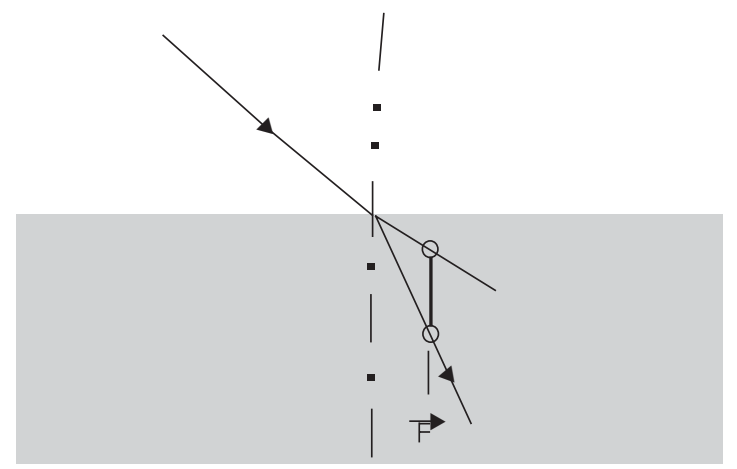

Figura 2b. O fenômeno da refração segundo a teoria corpuscular da luz (INEP, 2000).

Uma das contribuições fundamentais da epistemologia histórica de Bachelard é a primazia conferida ao permanente processo de reconstrução do saber científico, ao traço descontinuista da razão. A ciência é expressão de contínuas reformas: um novo pensamento sempre desencadeia rompimento com estruturas conceituais solidamente firmadas.

O cenário que passa a se delinear evidencia, então, o seguinte paradoxo: em determinadas situações a luz manifesta comportamento de partícula, como no efeito fotoelétrico; em outras, como na experiência de Young, assume caráter tipicamente ondulatório. Uma única teoria com a função de explicar e descrever fenômenos distintos, como os suscitados, era insuficiente.

O confuso e aparentemente contraditório comportamento da luz, articulado às investigações da radiação térmica de corpo negro, explicita insuficiências da física clássica quando trata das interações da radiação com a matéria. De um lado, Einstein interpreta o efeito fotoelétrico (1905) concebendo a luz como constituída de quanta de energia; por outro lado, Planck constata que os átomos emitem e absorvem energia de forma discreta. Assim, questionam a física clássica, lançando as bases conceituais de um novo domínio, o universo quântico (ROCHA, 2002).

Bachelard (1999, p. 20) realça que:

(...) as crises de crescimento do pensamento implicam uma reorganização total do sistema de saber. A cabeça bem feita precisa então ser refeita. Ela muda de espécie. Opõe-se à espécie anterior por uma função decisiva. Pelas revoluções espirituais que a invenção científica exige, o homem torna-se uma espécie mutante, ou melhor dizendo, uma espécie que tem necessidade de mudar, que sofre se não mudar. (...) Se considerarmos, por exemplo, a modificação psíquica que se verifica com a compreensão de doutrinas como a da Relatividade ou como a da Mecânica Ondulatória, talvez não achemos tais expressões exageradas (...)

Conforme Bachelard, a cultura científica caracteriza-se essencialmente por descontinuidades. À medida que um conceito se modifica, e com o aparecimento de novos conceitos, 
rompe-se com o saber sedimentado, renovando suas bases. As mudanças extrapolam o âmbito puramente científico, resultando, muitas vezes, em profundas rupturas nas convicções filosóficas dos cientistas, como a perspectiva dual da luz: trata-se, pois, de uma nova racionalidade.

Segundo Santos (1991, p. 135), no que concerne ao referencial bachelardiano a idéia de descontinuidade tem como premissa básica que “(...) o antes e o depois do conhecimento científico são irredutíveis um ao outro e que, por isso, são distintos". O autor continua, sugerindo que:

(...) enquanto a tese continuista defende que o presente da ciência depende do seu passado, que a ciência adiciona inovações, Bachelard defende que o passado não perspectiva o futuro, que a ciência não aglutina descobertas, antes as retifica e reorganiza; que o pensamento científico não desliza harmoniosamente de uma descoberta a outra; que as ligações entre as velhas e as novas teorias não são mecânicas não conduzem diretamente daquelas a estas; que muitas destas ligações só, a posteriori, são determinadas. Sublinha que o processo da ciência não é linear, nem unívoco, mas dialético, descontínuo e inacabado. (p. 135)

A defesa do progresso contínuo da razão, isto é, da evolução contínua da ciência, é sustentada basicamente por quatro suposições ou teses fundamentais, enunciadas a seguir com o respectivo contraponto de Bachelard (2001, p. 193-195):

Tese 1:

As graduais transformações evidenciam o percurso linear e crescimento cumulativo do conhecimento científico, de acordo com os continuistas.

\section{Crítica e contraponto:}

Entretanto, conforme Bachelard, as lentas transformações na construção de conceitos, de idéias e teorias na ciência mascaram crises, remodelações e profundas rupturas na essência desses conhecimentos, revelando mudanças científicas, e não sinais de continuidade.

Tese 2:

O êxito da ciência é fruto da ação de cientistas que capturam idéias que permeiam o ar, conforme a proposição continuista, justamente porque 'as idéias atuais são entendidas como préexistentes de forma embrionária em épocas anteriores:

\section{Crítica e contraponto:}

Compreendida desta forma, segundo Bachelard, desconsideram-se as concepções de mundo de uma época ou momento histórico.

\section{Tese 3:}

A ciência é vista como extremamente fácil e simples, já que o conhecimento científico ancora-se ao conhecimento do senso comum. Nesses termos, o saber escolar assume a função de ponte entre essas estruturas conceituais.

\section{Crítica e contraponto:}

Para Bachelard, essa idéia está equivocada, porque a ciência e o senso comum cumprem funções distintas nas explicações que tecem sobre as coisas: o compromisso da primeira 
Melo, A. C. S.; Peduzzi, L. O. Q.

com o rigor, seus procedimentos e suas práticas constituem um corpo teórico de racionalidade distinta das idéias geradas de forma espontânea no senso comum.

Tese 4:

Julga-se simples estender as imagens e a linguagem da ciência clássica (ou do senso comum) para o âmbito da física contemporânea, estabelecendo de forma direta esta ligação.

\section{Crítica e contraponto:}

Entretanto, a ciência quântica, intangível aos sentidos, não pode ser traduzida de forma completa pelas imagens, analogias e metáforas (linguagem) da esfera do senso comum ou da física clássica. Para Bachelard, estes recursos, quando utilizados para representar o universo microscópico, devem ser colocados sempre entre aspas, pois não refletem fielmente este domínio. Assim, a linguagem e as imagens são expressões de constantes redefinições e resignificações na medida em que caminham de uma racionalidade a outra. Em cada contexto deve haver clareza do alcance, por conseguinte, dos limites das imagens, analogias e metáforas.

A perspectiva de um encadeamento lógico de idéias, de conceitos e de teorias revela um traço marcante da imagem tradicional do fazer ciência, encerrando o conhecimento científico a uma sucessão de verdades (passos corretos) que se agregam ao longo do tempo. Com efeito, acredita-se que na história da ciência o erro não só não tem lugar, como sua inexistência, tal como é concebido pela corrente positivista, pode ser evidenciada no decurso da história do pensamento científico, tendo em vista que um conhecimento soma-se a outro. Para Bachelard, contrariamente, um conhecimento se dá contra outro, retificando constantemente os erros, superando entraves e dificuldades em seu percurso. O conhecimento científico não está encerrado a uma visão estanque e definitiva: contrariamente, configura-se dinâmico e vivo.

A história da óptica ilustra as rupturas que ocorrem no decorrer do desenvolvimento dessa ciência, forçando o espírito científico a pensar e repensar constantemente a forma de ver os fenômenos luminosos. As mudanças de perspectivas da ciência, distintas trajetórias percorridas para alcançar conhecimentos, apontam o profundo dinamismo dessa atividade, que, segundo Bachelard, exige a renúncia constante de bases filosóficas ultrapassadas.

As oscilações entre as teorias corpuscular e ondulatória da luz evidenciam, para Bachelard (1999), que a verdade constitui-se provisória; o erro, neste sentido, assume papel positivo e inerente à prática científica. Contudo, o erro valorizado por Bachelard é aquele pensado, que surge não de forma gratuita e distraída, mas fruto do esforço do pensamento.

De acordo com a perspectiva tradicional, o erro configura-se um 'acidente lamentável', 'um equívoco', 'uma anomalia a ser arrancada' da prática científica, pois torna o conhecimento falível, estéril e infecundo. Nestes termos, deve ser condenado e suplantado por completo em qualquer atividade que exija a construção de conhecimento, seja no espaço escolar ou campo científico - idéia que não tem lugar na epistemologia histórica de Bachelard.

A primazia em geral conferida à verdade no ato de conhecer desconsidera o valor do erro na construção do saber e sua presença constante nesse percurso. Segundo Bachelard (1999), o erro é o elemento motor do desenvolvimento da ciência por propiciar as condições necessárias para seu avanço.

Como ressalta Lopes (1996b, p. 252), para Bachelard "precisamos errar em ciência, pois o conhecimento científico só se constrói pela retificação desses erros". Assim, a noção de 
verdade se modifica. Não existe verdade inquestionável, conhecimento inviolável que permaneça cristalizado ao longo da história. Toda idéia tem caráter efêmero, está sujeita a tornar-se obsoleta. Esta característica da evolução de conceitos, idéias e teorias científicas mostra as constantes rupturas que se estabelecem no avanço de uma trajetória histórica, já que a verdade não se configura definitiva, mas provisória. O conhecimento é concebido como móvel, dinâmico, em detrimento de uma imagem estanque (BACHELARD, 1975).

\section{A história recorrente de Bachelard e as controvérsias sobre os espelhos ardentes de Arquimedes}

As ambigüidades do debate concernente à possível façanha de Arquimedes (incendiar os navios romanos com espelhos ardentes ${ }^{5}$ para salvar Siracusa) suscitam diversas especulações no âmbito da história da ciência. De um lado, alguns historiadores defendem que o espetacular efeito dos espelhos ardentes é, de fato, verdadeiro; outros reúnem argumentos contrários, para afirmar que Arquimedes não utilizou esses dispositivos.

Com base nisso, qual o papel da análise crítica no estudo da história do pensamento científico? Pontos polêmicos, alvo de contestações, como este, devem incitar a discussão crítica e reflexiva do aluno ou deve-se dar primazia à imparcialidade nas discussões históricas, para que esses contrastes e controvérsias não causem descrédito e confusão de idéias com relação à ciência?

De acordo com a postura de Bachelard, o estudo da natureza e a construção do conhecimento científico devem se pautar na análise crítica, que pensa, investiga, examina, aprecia e censura, quando necessário. Para Bachelard (2001, 1999), no ensino de ciências, a articulação da história da ciência à epistemologia é de primordial relevância para a desmistificação de imagens equivocadas sobre o empreendimento científico e contextualização dos conteúdos. As controvérsias exploradas no debate sobre os espelhos ardentes de Arquimedes ensejam justamente aprimorar ações e postura crítica dos alunos, sendo, portanto, de grande valor.

Conforme Bachelard (1975), o resgate da história do pensamento científico deve ser objeto de viva e intensa crítica. Submeter conceitos, idéias e teorias de uma época a um severo julgamento, considerando como referencial o estado presente da ciência, para efeito de reflexão, propicia um vislumbre dos erros e acertos dos cientistas no decurso da construção do conhecimento científico.

$\mathrm{Na}$ defesa dessa postura, Bachelard não intenta depreciar o valor da gênese e do desenvolvimento da ciência - vendo, no passado, um emaranhado de equívocos e erros - ou desconsiderar o contexto histórico - vinculado à estruturação de um conhecimento. Deseja apresentar os esforços da razão para atingir o estágio atual, o constante rompimento com o

\footnotetext{
${ }^{5}$ Espelhos ardentes ou espelhos incandescentes são espelhos com propriedades de convergir os raios que incidem em sua face paralelamente para um ponto, hoje conhecidos por espelhos côncavos.
} 
senso comum, com os limites dos sentidos, entendidos por longo tempo como suficientes e de inquestionável eficácia para o entendimento do mundo natural. Como acentua Bachelard, o real é luz que sempre projeta algumas sombras; com isso, não deve ser aceito imediatamente, pois, quando examinado em maior detalhe, nunca exprime o que a opinião primeira e as experiências sensoriais apreendem.

No âmbito do estudo histórico, é um ideal enganoso tentar retraçar o curso do conhecimento científico reportando-se a determinado momento histórico de forma supostamente neutra. O pensamento está imbuído de uma carga de concepções referenciadas na ciência atual, que devem, por sua vez, conduzir o estudo histórico, apontando a complexa trajetória científica na busca da verdade.

Aqui, o exemplo dos espelhos ardentes de Arquimedes pode ser suscitado, articulando a idéia de recorrência histórica de Bachelard (que ressalta a importância de apreciar criticamente a história da ciência) às discussões ressaltadas por Thuillier (1994) sobre este possível episódio histórico, considerado, por alguns historiadores, mero devaneio e, por outros, uma evidência incontestável.

A partir de seus conhecimentos de óptica, Descartes demonstra incredulidade acerca dos espelhos de Arquimedes: sustenta que para atingir essa façanha seria inevitável a construção de um espelho gigantesco - impossível para os recursos técnicos da época; que, mesmo dispondo de um espelho com tais dimensões, ainda haveria dúvidas sobre a intensidade dos raios solares necessária para queimar os navios romanos.

Estudiosos da Idade Média, mais tarde Galileu Galilei, entre outros, que expressavam admiração pelo sol, como corpo celeste, não apenas aventavam a possibilidade do episódio polêmico dos espelhos incandescentes, como acreditavam na sua legitimidade. Em 1646, por exemplo, a partir de suas próprias experiências o padre jesuíta Athanasius Kircher "constata que, com cinco espelhos planos, dispostos judiciosamente, obtém-se um calor quase intolerável a mais de cem pés (33 metros) de distância. Com uma quantidade maior de espelhos, os efeitos serão ainda mais espetaculares". (THUILLIER, 1994, p. 37).

No Renascimento, vários autores se engajam na construção de espelhos ardentes, dedicando com detalhes obras inteiras a essa discussão, como Oronce Fine, matemático que concebe como mais eficaz o espelho parabólico, em detrimento do esférico.

$\mathrm{Na}$ tentativa de acabar com o impasse, no século XVIII o físico francês Du Fay combina um espelho côncavo e um parabólico seccionado. Sem lograr êxito, considera insustentável e absurda a proposição histórica. Conforme salienta Thuillier (1994, p. 38):

(...) é Buffon quem dá a contribuição mais espetacular para a discussão. Pela prática, isto é, construindo ele mesmo um espelho formado por 168 vidros de pequeno tamanho e o experimentando em materiais diversos, mostra, em 1747, que Descartes estava errado. Porque os raciocínios abstratos não importam: o fato é que é possível atear fogo muito depressa à madeira com um espelho composto.

${ }^{6}$ Para Bachelard e para a filosofia contemporânea da ciência a verdade é entendida como provisória, de caráter efêmero. 
No entanto, contemporaneamente prevalece a idéia de que se trata de um episódio lendário. Thuillier (1994) ressalta que o inglês D. L. Simms, especialista em fenômenos de combustão, tece objeções acerca de três pontos fundamentais:

- As fontes históricas favoráveis à existência de espelhos ardentes não têm valor porque os três historiadores que deixaram os melhores relatos do cerco de Siracusa (Políbio, Tito Lívio e Plutarco) não fazem qualquer alusão a espelhos ardentes;

- Arquimedes não dispunha de meios (intelectuais e técnicos) para construir uma arma solar tão potente: precisaria dos conhecimentos teóricos sobre as propriedades locais do parabolóide e sobre como os espelhos desencadeiam a combustão, fato que, segundo seus argumentos, não se evidencia. A partir de um laudo técnico, Simms constata que os célebres espelhos de Arquimedes não seriam capazes de destruir as tropas romanas.

- Nas condições concretas do cerco de Siracusa, uma proeza desse gênero jamais teria sido bem sucedida.

Ainda de acordo com Thuillier (1994, p. 47):

Embora pretenda arruinar a lenda dos espelhos ardentes, D. L. Simms é praticamente forçado a concordar: o 'paradigma' da ciência, no final do século III a.C. era bastante rico para fornecer todos os elementos necessários à concepção dos famosos espelhos. Não nos esqueçamos, além do mais, que muito antes de Arquimedes os gregos já se interessavam pelos fenômenos de reflexão e refração, bem como por suas aplicações práticas.

A apreciação crítica dos historiadores ao se reportarem a esse embate evidencia uma história da ciência pouco consensual e pacífica. A efervescência de idéias que decorrem do estudo recorrente da história - que julgada, sentenciada e avaliada com o rigor da ciência atual inspira atitude reflexiva sem, contudo, desmerecer o papel relevante e essencial da história do pensamento científico - contribui para a análise da legitimidade de determinado episódio histórico, como no caso dos espelhos ardentes de Arquimedes.

\section{Analogias na evolução da óptica: uma análise a partir da perspectiva bachelardiana}

Qual o papel das analogias, metáforas e imagens na gênese e no desenvolvimento das teorias científicas? Com que freqüência os cientistas apelam a essas ferramentas da linguagem e do pensamento? $\mathrm{O}$ uso desenfreado e excessivo do arsenal analógico e metafórico constitui elemento motor do conhecimento, agindo positivamente sobre o empreendimento científico? Ou é causa de entraves à evolução do pensamento científico?

Bachelard $(1999,1975)$ confere especial destaque à questão das analogias, metáforas e imagens, apontando cuidados em relação ao uso abusivo dessas expressões da linguagem, que muitas vezes formam obstáculos e resistências ao avanço da ciência.

Em virtude de uma compreensão inadequada desses mecanismos explicativos, o pen- 
samento científico manifesta a tendência de contemplar as analogias, metáforas e imagens como "uma afirmação dogmática da realidade", ideal fortemente criticado por Bachelard (LOPES, 1996b, p. 263).

Santos (1991, p. 141) ressalta que, de acordo com Bachelard: "há que desqualificar imagens e metáforas quando pretendem ser imagens-reflexos, mais ou menos exatas, de uma realidade oferecida à investigação, ou seja, quando pretendem passar por cópias fiéis dessa realidade".

Com efeito, Bachelard (1975, p. 84) evidencia que: "as imagens ${ }^{7}$ (...) são ao mesmo tempo boas e más, indispensáveis e prejudiciais, é preciso usá-las com medida enquanto são boas e desembaraçar-se imediatamente delas quando se tornam prejudiciais".

A história do pensamento científico, para Bachelard, mostra que a ciência caminha contra o conhecimento comum, afastando-se do concreto e do perceptível, investindo contemporaneamente em áreas cada vez mais especializadas. Contudo, a necessidade de inferir conclusões sobre o desconhecido, objetivando simular os comportamentos da natureza requer, com freqüência, conexões com o que é observável, com imagens e com modelos concretos, para que relações analógicas possam tornar os conhecimentos não familiares acessíveis e inteligíveis.

No exemplo da evolução da óptica, ao desenvolver a teoria ondulatória da luz, Huygens faz uso de uma analogia com o som e define a luz como uma vibração mecânica (ROCHA, 2002; PIETROCOLA, 1993).

Uma analogia incorreta, como salienta Bachelard, pode desencadear alguns equívocos na construção de uma teoria e, até mesmo, distorção na compreensão de um conceito ou uma idéia. A analogia com o som evidencia isso: por se acreditar que o comportamento da luz não era apenas semelhante, mas idêntico ao do som, durante um longo período permaneceu hegemônica a crença na existência de um meio (éter) necessário para sua propagação. Nesse caso, Bachelard afirma que a analogia constitui um obstáculo epistemológico à idéia correta das ondas eletromagnéticas, que não necessitam de um meio para se propagar.

Essa tendência do pensamento - utilização de recursos analógicos - é manifesta também nas investigações referentes à dupla refração que desencadeiam estudos sobre fenômenos de polarização. Newton, por exemplo, na tentativa de construir uma explicação satisfatória ao fenômeno de polarização da luz observado por Huygens, imagina os raios luminosos como constituídos de uma estrutura com propriedades distintas, em diferentes direções, transversais à direção de propagação (ROCHA, 2002), estabelecendo uma analogia entre os possíveis lados do raio luminoso e os pólos de um ímã.

Não obstante, nessa mesma linha de raciocínio analógico, Malus, em 1809, ao detectar a polarização por reflexão, concebe como causa desse fenômeno a atuação de forças repulsivas do meio sobre as moléculas que compõem os raios luminosos. Analogamente às partículas magnéticas que se orientam sob a ação de um imã, ao incidir sobre uma superfície mais refringente o raio luminoso sofre a influência das forças repulsivas daquele meio que, além de se responsabilizarem pela reflexão, exercem ação sobre a orientação dos eixos das moléculas luminosas, que ficam dispostos paralelamente.

${ }^{7}$ Pode-se estender sua afirmação acerca das imagens para analogias e metáforas. 
Em síntese, Bachelard ilustra que o discurso científico não é literal, objetivo e transparente; apropria-se, muitas vezes, desses recursos lingüísticos para dar significado a aspectos não observáveis do mundo natural. Contudo, a crítica bachelardiana ao uso incorreto das analogias, metáforas e imagens procura realçar que, como correspondem a modelos de raciocínio com limites de aplicabilidade, nunca constituem retrato fiel do real.

A pretensão de um discurso científico livre de expressões metafóricas e analógicas é contestada por Contenças (1999), que atribui inegável valor a esses recursos nos processos de significação de conhecimentos. A linguagem não é transparente e estanque: apropria-se deliberadamente de analogias e metáforas para comparar domínios de gêneros distintos e aproximar noções de natureza complexa ao universo familiar.

Atualmente, extensa literatura (CONTENÇAS, 1999; FERRAZ e TERRAZAN, 2003; ISABEL e NAGEN, 2002; FERRAZ, 2000; DAGHER, 1995; HARRISON e TREAGUST, 1994; MARTINS, 1998; CURTIS e REAIGELUTH, 1984) indica o raciocínio analógico como elemento essencial para tornar significativos aspectos não observáveis do mundo natural. Afirmar que as analogias e metáforas fazem parte apenas de estágios iniciais do pensamento da ciência - ou que o estilo científico não recorre em momento algum a esses recursos, dispondo sempre de uma linguagem literal, ordenada e rigorosa - caracteriza uma idéia ingênua e falaciosa do discurso científico, que tem sua raiz na concepção empírico-indutivista.

ciência:

Contenças (1999, p. 66) afirma que de acordo com essa concepção equivocada da

(...) a descrição e a explicação da realidade são tarefas da ciência e só a linguagem literal é adequada para a caracterização objetiva desta realidade. A linguagem científica deve ser rigorosa, objetiva, apresentando os conceitos com conteúdo unívoco, de modo a possuir um estatuto racional e atemporal. Por isso, deve excluir a fantasia, a imaginação e as preferências subjetivas do gosto... a linguagem formal resultante dos sistemas dedutivos é a única que a ciência deve usar, ignorando, deste modo, a metáfora e a analogia... Só a linguagem literal é empiricamente respeitável.

As exposições científicas de teses teóricas e leis mostram que o discurso da ciência se apropria deliberadamente da linguagem metafórica e analógica. Contudo, os caminhos que conduzem à descoberta científica, as idas e vindas presentes na trajetória do cientista, em geral suprimidas na comunicação de textos científicos, mascaram as diversas facetas da linguagem presentes na atividade científica (TERRAZAN, 2000; UTGES, 1999).

A polêmica referente à contaminação retórica causada pelas analogias e metáforas na linguagem da ciência apresenta-se bastante polarizada: de um lado, autores admitem que os recursos metafóricos e analógicos imperam unicamente na gênese e no contexto de criação de teorias; outros defendem que a linguagem ambígüa (metafórica e analógica) revela-se tanto na elaboração quanto na difusão das teorias, permanecendo em estágios iniciais e avançados da pesquisa científica.

Contenças (1999, p. 67) assinala que "a história da ciência mostra-nos que desde sempre a linguagem científica inclui expressões metafóricas", recorrendo constantemente às analogias e metáforas como ferramentas da comunicação e do próprio pensamento.

Nesta perspectiva, Arruda (1993) apresenta um breve estudo sobre as mudanças con- 
Melo, A. C. S.; Peduzzi, L. O. Q.

ceituais introduzidas por Einstein, em 1905. Buscando discutir as possíveis relações entre as revoluções científicas e algumas mudanças significavas na linguagem metafórica presente no contexto da ciência, destaca que:

(...) a linguagem científica, supostamente exata e objetiva, está permeada de contruções metafóricas... Os físicos criam um universo próprio formado por pontos materiais, campos, átomos e radiações através dos quais vêem o mundo... inventamos um universo para poder entender e falar sobre a realidade e prever novos fatos. (ARRUDA, 1993, p. 35)

As contribuições da epistemologia histórica de Bachelard e os recentes estudos da lingüística têm potencializado a aceitação de uma postura mais flexível concernente à presença desses recursos da linguagem na atividade científica, desmistificando a imagem tradicional do 'fazer ciência'.

\section{As novas perspectivas da ciência contemporânea à luz da epistemologia bachelardiana}

\section{Diálogo entre a razão e a experiência: o papel do instrumental técnico na física contemporânea}

De acordo com a corrente empirista, nos moldes tradicionais, o conhecimento confiável advém da experiência alheia a pressupostos teóricos, à imaginação, intuição e a especulações de qualquer gênero. Os fatos se apresentam de forma pura e transparente ao cientista que, paciente e atento, captura o que a natureza revela. Já a doutrina racionalista atribui a origem do conhecimento à razão.

A hegemonia conferida à razão ou à experiência como fonte única do conhecimento confiável orientou diversas discussões entre filósofos da ciência (PRAIA et al., 2002). Ao defender a necessidade de novo espírito científico articulado às novas ciências do século XX, Bachelard (1975) destaca que não se pode conceber o racionalismo e o empirismo como posturas epistemológicas antagônicas, isto é, atribuir o conhecimento a esforços exclusivos de uma ou outra vertente. A 'verdade' se revela ao cientista no diálogo constante entre o racional e o empírico. Entretanto, um traço marcante da epistemologia histórica de Bachelard refere-se à primazia conferida às construções racionais, que necessariamente precedem, tornam possível e organizam a experiência.

No que diz respeito às idéias de Bachelard (1975, p. 8), a noção de experiência, relacionada à física contemporânea, não está ligada ao real dado, sensível aos sentidos, que valoriza, sobretudo, o 'percebido', o 'imaginado', mas, sim, a uma realidade construída pela técnica, à qual o autor denomina "fenomenotécnica". Os instrumentos e artefatos tecnológicos mediam sujeito e objeto do conhecimento, distanciando o real científico (objeto científico) do senso comum. $\mathrm{O}$ fenômeno não é dado, mas encontra-se indissociavelmente ligado a uma realidade construida pela técnica. 
A dialética racionalismo-empirismo e o valor do instrumental técnico podem ser explorados no exemplo da síntese teórica de De Broglie acerca da natureza dual do elétron. Guiado essencialmente pela idéia de que uma das características fundamentais da natureza é o princípio de simetria, De Broglie estendeu a dualidade onda-corpúsculo das ondas para as partículas materiais. Conforme Bachelard (1975, p. 233) “(...) não se conhecia nenhum 'fenômeno eletrônico' que pudesse receber uma interpretação ondulatória. Como o empirismo não oferecia nada, o racionalismo deveria fazê-lo. O problema deveria ser abordado por via de construções racionais (...)". Configura-se, assim, uma filosofia do movimento, de acordo com a perspectiva bachelardiana, ilustrando o diálogo constante entre a razão e a experiência. Corroborada mais tarde pela experiência de difração de elétrons, a intuição teórica de De Broglie conferiu a ele o mérito de ser um dos fundadores da mecânica quântica.

Conforme ressaltam Halliday et al. (1995, p.147):

Foram raras as vezes em que os físicos se enganaram ao confiar nas simetrias da natureza. Por exemplo, depois de sabermos que um campo magnético variável produz um campo elétrico, faz sentido pensarmos (e de fato é verdade) que um campo elétrico variável produza um campo magnético. Sabia-se que o elétron possuía uma antipartícula (uma partícula de mesma massa, mas de carga oposta), e podia-se imaginar que o próton também tivesse uma antipartícula. Para confirmar esta hipótese, construiu-se um acelerador de prótons, com uma energia adequada, e o antipróton foi descoberto [detectado].

Os registros experimentais obtidos a partir do dispositivo construído por Davisson e Germer (figura 3), corroboram o pressuposto teórico de De Broglie: a matéria, tradicionalmente analisada como um conjunto de partículas, possui propriedades ondulatórias. Desenvolvido especificamente para medir comprimentos de onda de elétrons, representa a concepção de Bachelard com relação ao que é a experiência na física quântica. O fenômeno não está na natureza, apresenta-se a partir de uma técnica.

De forma independente, em 1927 George Thomson ${ }^{8}$ também chega aos mesmos resultados a partir de experimentos similares ao de Davisson-Germer (figura 4). Tanto Thomson quanto Davisson receberam o prêmio Nobel pelos trabalhos.

Segundo Bachelard, o processo de organização do pensamento determina a construção do objeto científico nas ciências físicas do século XX, que transcende os fenômenos 'disponíveis' espontaneamente no mundo natural. A ciência contemporânea trabalha com um mundo recomeçado, reconstruído e reestruturado pelo arsenal instrumental e técnico, rompendo com o saber comum, fonte de erros, enganos e distrações do pensamento:

\footnotetext{
${ }^{8}$ Filho de J. J. Thomson, George Paget Thomson evidencia, por meio de experimentos de difração de elétrons, que eles realmente podem apresentar comportamento ondulatório.
} 
Melo, A. C. S.; Peduzzi, L. O. Q.

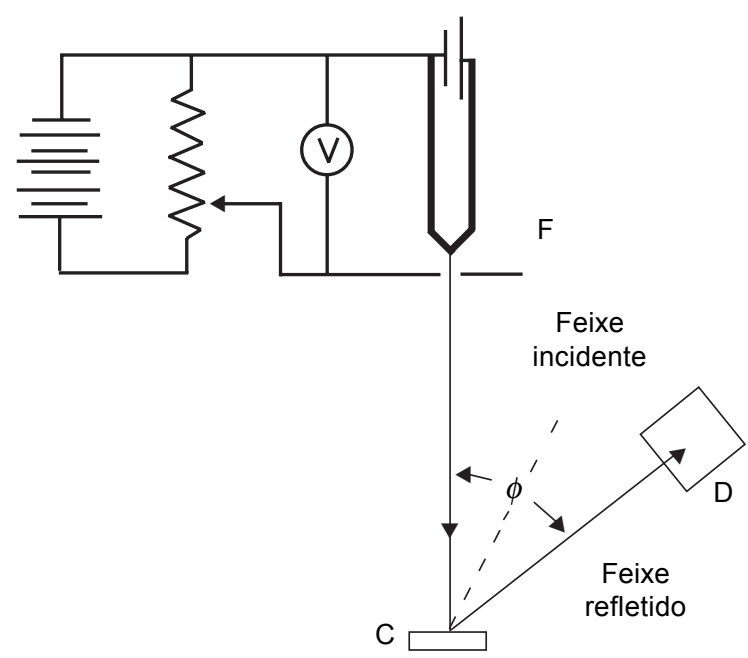

Figura 3. Experimento de Davisson-Germer: elétrons são emitidos por um filamento $\mathrm{F}$ e acelerados pela diferença de potencial variável V. Depois de serem refletidos pelo cristal C, eles são registrados pelo detector $D$ [obtém-se uma figura de interferência], que pode ser movido por várias posições angulares $\phi$. (HALLIDAY et al., 1996, p.150).

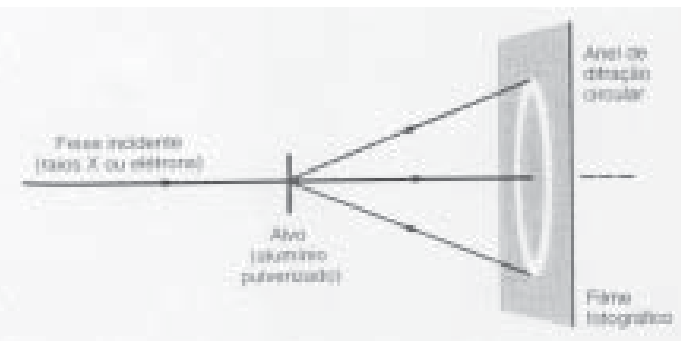

Figura 4a

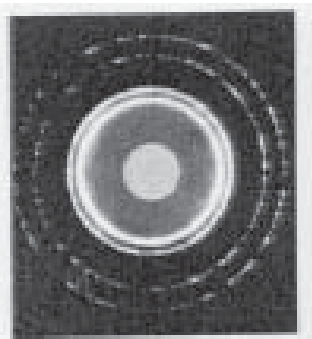

Figura $4 b$

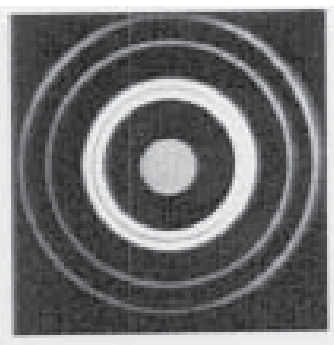

Figura 4c

Figura 4. Experimento de George Thompson: 4a: um padrão de interferência é produzido utilizando um alvo pulverizado ou cristalino; $4 \mathrm{~b}$ : o padrão de difração de raios $X$ de um alvo de alumínio pulverizado; 4c: o padrão de difração de elétrons para o mesmo alvo. A energia do elétron foi escolhida de modo que o comprimento de onda de De Broglie seja igual ao comprimento de onda dos raios X em b. (HALLIDAY et al., 1996, p. 151). 
A ciência de hoje em dia é deliberadamente 'especializada' ... Rompe com a natureza para construir uma técnica. Constrói uma realidade, esculpe a matéria, dá finalidade às coisas dispersas. Construção... é aqui o trabalho humano, é aqui o trabalho científico. (BACHELARD, 1975, p. 10)

Nesse sentido, a ciência não dedica espaço apenas a elementos observáveis nela apresentados, como advoga a visão empírico-indutivista. A confiabilidade decretada somente às inferências teóricas obtidas a partir da observação, fonte primeira do conhecimento, é revisada pela filosofia histórica de Bachelard, que aponta a construção do objeto científico como principal motor da atividade científica contemporânea. A experiência da fenda dupla de Young, o interferômetro de Michelson-Morley e a difração de elétrons indicam o papel fundamental do instrumental técnico mediando sujeito e objeto do conhecimento.

O interferômetro de Milchelson-Morley (figura 5), construído em 1887 para medir a velocidade da luz no éter, meio que até então se acreditava necessário para sua propagação, acabou por refutar a hipótese teórica da presença do éter. Este exemplo específico explicita, além da relevância dos dispositivos técnicos na ciência, a importância do diálogo entre razão e experiência, característica acentuada na epistemologia histórica de Bachelard, fundamentalmente no que se refere às ciências contemporâneas.

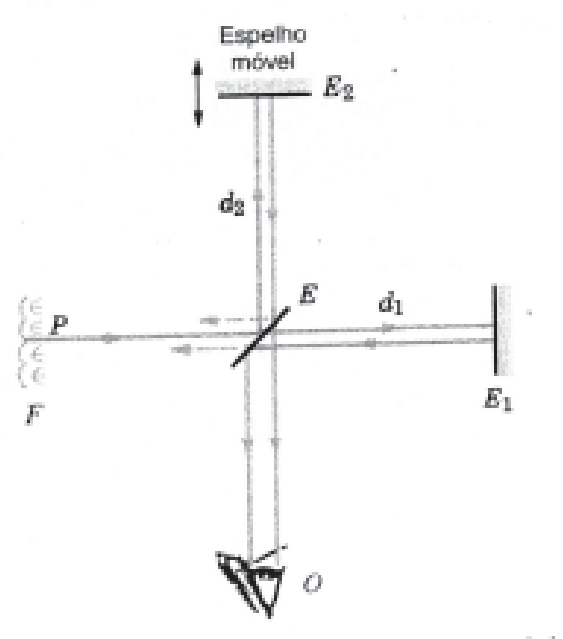

Figura 5. Interferômetro de Michelson-Morley: o espelho $M$ divide a luz em dois raios, que são refletidos pelos espelhos $M_{1}$ e $M_{2}$ de volta para $M$ e, daí, para o telescópio $T$. No telescópio, o observador vê uma figura de interferência. (HALLIDAYet al., 1995, p. 75).

"O termo original utilizado por Bachelard em sua obra "A atividade racionalista na física contemporânea" é factícia, em vários momentos suscitado pelo autor para designar uma característica essencial da cultura científica contemporânea. A construção do objeto científico evidencia essa ciência especializada, dirigida à investigação detalhada de um fato em oposição à generalidade. 
Este exemplo explicita a relação entre racionalismo e empirismo, evidenciando que a dialética entre estas duas posturas filosóficas caracteriza o avanço da ciência, de acordo com Bachelard. Tendo em vista que o éter mostrou não ter qualquer efeito sobre a velocidade da luz, o resultado propiciou uma revisão de sua hipótese teórica. Os registros experimentais e, mesmo, simples observações não se sustentam sem um pilar teórico. Contudo, a teoria deve ser rivalizada com os dados, podendo apresentar falhas ou estar susceptível a tornar-se obsoleta. Além de assinalar este aspecto, Bachelard caracteriza a importância de uma 'conversa' entre o que a experiência diz e o que a teoria prevê. Nessa troca, ambas são questionadas, interrogadas, submetidas a constantes problematizações (BACHELARD, 1975).

No episódio histórico explorado, as previsões da existência do éter, confrontadas com sucessivos registros experimentais, sugerem uma revisão da hipótese teórica, dado o caráter negativo da experiência de Michelson-Morley, que explicita, o diálogo entre razão e experiência.

Com o engenhoso dispositivo, Michelson e Morley receberam o prêmio Nobel, fundamentalmente em virtude da construção do instrumento técnico, embora o resultado alcançado seja de inegável reconhecimento. Pode-se perceber, neste caso e no exemplo da difração de elétrons, o valor da técnica na estruturação de uma teoria na física contemporânea, que trata de fenômenos detectáveis somente a partir do experimento.

Por enfatizar essas novas perspectivas das ciências físicas propiciadas pelo advento da ciência quântica, Bachelard constitui referencial importante para o estudo da evolução do pensamento científico. A percepção bachelardiana de formação do novo espírito científico, ressaltada ao longo da história da óptica, ilustra, em virtude dos exemplos explorados, que o conhecimento atual nas ciências físicas está diretamente ligado aos instrumentos técnicos, evidenciando a estrita ligação entre teoria e técnica. A técnica é uma teoria materializada.

\section{Considerações finais}

O artigo buscou ilustrar uma análise da história da óptica à luz da interpretação bachelardiana da ciência, com objetivo de evidenciar a pertinência da articulação entre história e filosofia da ciência para uma visão crítica da construção do conhecimento científico. A abordagem histórico-epistemológica da ciência pode proporcionar um contraste à imagem da ciência concebida pelo senso comum e caracterizada, entre tantas outras coisas, como atemporal e ahistórica. Isso contribui para que a imagem da relação entre cientista e natureza não se encerre em uma objetividade indiscutível e absoluta, mas retrate um trabalho humano, uma atividade intelectual, psicológica e socialmente condicionada (THUILLIER, 1994).

Como menciona Anderson (1968), com base no prefácio do livro Termodinâmica, de Lewis e Randall, a investigação científica se assemelha à montagem de um quebra-cabeças muito especial, porque não configura uma imagem definitiva. As peças, desordenadas nas etapas iniciais, contemplam um pro-blema a ser resolvido, sem indicações da imagem que será formada; porém, os objetivos claros e bem determinados indicam o propósito da atividade. À medida que as peças se encaixam, algu-mas vezes fica evidente qual deve ser o passo seguinte. No entanto, em outros momentos há sur-presas, aparecendo uma situação imprevista, tomando-se um ponto de vista completamente dife-rente do anterior. A ciência caminha dessa forma. Quando a ênfase é conferida apenas ao resul-tado, ocultam-se as "idas e vindas" do pesqui- 
sador - as mudanças nas trajetórias encerrando pers-pectivas, às vezes, totalmente diferentes das concepções admitidas inicialmente:

Os que escrevem sobre a metodologia científica observam o quadro quando está terminado e dão ênfase à sua beleza e sua evidente estrutura lógica; mas aqueles que contribuíram na sua realização têm uma experiência completamente distinta; uma experiência com mais frustrações e insatisfações do que aquele que vê unicamente os resultados. (ANDERSON, 1968)

Caracterizar a ciência, sua natureza e construção; desmascarar visões ingênuas da gênese e do desenvolvimento do conhecimento científico e da própria filosofia da ciência configuram-se desafios presentes no ensino das ciências naturais, tanto em nível médio, quanto universitário. Que ciência se estuda? Qual o papel da história e da filosofia da ciência no ensino em geral? Qual a imagem da ciência que se deve articular ao ensino de ciências? A idéia de um cientista estritamente racional, neutro e objetivo, que segue rigorosamente o método? Ou retratar um cientista que falha e erra muitas vezes, em uma perspectiva mais humana da ciência?... Essas questões podem inspirar e despertar o ensino de Física de seu sono dogmático: o sono de um conhecimento apresentado acriticamente.

De fato, para que o ensino de Física não seja responsável pela construção de uma imagem equivocada do empreendimento científico, ele deve-se reportar à formação inicial de professores e pesquisadores. Uma disciplina que discorra sobre a evolução dos conceitos da Física, por exemplo, pode ser espaço rico para discussões com ênfase à natureza históricofilosófica da ciência 'física'. Contudo, muitos cursos nem sequer reservam uma disciplina a essa história em seus currículos; ou, quando o fazem, dão primazia a uma abordagem histórica essencialmente seqüencial (STAUB e PEDUZZI, 2003).

A história da óptica articulada à filosofia bachelardiana exemplifica um possível diálogo entre história e filosofia da ciência em uma disciplina de natureza histórica junto a um curso de Física, tendo em vista que uma visão crítico-reflexiva deve, necessariamente, acompanhar o estudo da evolução do pensamento científico. E isto não pode ser feito mencionando apenas os resultados da ciência em ordem meramente cronológica. 
Melo, A. C. S.; Peduzzi, L. O. Q.

\section{Referências}

ABRANTES, P. Imagens de natureza, imagens de ciência. São Paulo: Papirus, 1998.

ANDERSON, D. L. El descubrimiento del electron. México: Editorial Reverté Mexicana, 1968.

ARRUDA, S. M. Metáforas na Física. Caderno Catarinense de Ensino de Física, Florianópolis, v.10, n.1, p. 25-37, 1993.

BACHELARD, G. Epistemologia. Lisboa: Edições 70, 2001.

A formação do espírito científico. Rio de Janeiro: Contraponto, 1999. O materialismo racional. Lisboa: Edições 70, 1990.

. A filosofia do não. São Paulo: Abril Cultural, 1979a. O novo espírito científico. São Paulo: Abril Cultural, 1979b.

La actividad racionalista de la física contemporanea. Buenos Aires: Editorial Siglo Veinte, 1975.

BARTHEM, R. A Luz. São Paulo: Editora Livraria da Física/Sociedade Brasileira de Física, 2005. (Temas atuais de Física)

BASSALO, J. M. F. Crônicas da Física. Belém: Editora UFPA, 1987.

BORGES, R. M. R. Em debate: cientificidade e educação em ciências. Porto Alegre: SE/ CECIRS/Secretaria Estadual de Educação do Rio Grande do Sul, 1996.

CASTRO, R. S. Uma e outras histórias. In: CARVALHO, A. M. P. (Org.). Ensino de Ciência: unindo a pesquisa e a prática. São Paulo: Pioneira Thomson Learning, 2004.

CONTENÇAS, P. A eficácia da metáfora na produção da ciência: o caso da genética. Lisboa: Instituto Piaget, 1999.

CURTIS, R. V.; REAIGELUTH, C. M. The use of analogies in written text. Instructional Science, Amsterdam, n.13, p. 99-117, 1984.

DAGHER, Z. Analysis of analogies used by science teachers. Journal of Research in Science Teaching, v. 32, n. 3, p. 259-270, 1995.

DELIZOICOV, N. C. O movimento do sangue no corpo humano: história e ensino. Florianópolis, 2002. Tese (Doutorado em Educação) - Centro de Ciências da Educação, Universidade Federal de Santa Catarina.

DRAKE, S. Galileu. Lisboa: Publicações Dom Quixote, 1981. 
Contribuições da Epistemologia Bachelardiana...

FERRAZ, D. F. O uso de analogias como recurso didático por professores de biologia no Ensino Médio. Santa Maria, 2000. Dissertação (Mestrado em Educação) - Universidade Federal de Santa Maria.

.; TERRAZAN, E. A. Uso espontâneo de analogias por professores de biologia e o uso sistematizado de analogias: que relação? Ciência \& Educação, Bauru, v. 9, n. 2, p. 213227, 2003.

FEYERABEND, P. Contra o método. Rio de Janeiro: F. Alves, 1977.

FREIRE JR., O.; et al. A relevância da filosofia e da história da ciência para a formação de professores de ciências. In: Arcádia, 2000. Epistemologia e Ensino de Ciências. Alagoas:

GIL-PÉREZ, D.; MONTORO, I. F.; ALÍS, J. C.; et al. Para uma imagem não deformada no ensino de ciências. Ciência \& Educação, Bauru, v. 7, n. 2, p. 125-153, 2001.

HALLIDAY, D.; RESNICK, R.; KRANE, K. S. Fundamentos de Física: ótica e Física moderna. 4. ed. Trad. Denise Helena da Silva Sotero et al. Rio de Janeiro:

Livros Técnicos e Científicos, 1995. v. 4.

. Física. 4. ed. Trad. Alexandre Carlos Tort et al. Rio de Janeiro: Livros Técnicos e Científicos, 1996. v. 4.

HARRES, J. B. S. Concepções de professores sobre a natureza da ciência. Porto Alegre, 1999. Tese (Doutorado em Educação) - Pontifícia Universidade Católica do Rio Grande do Sul.

HARRISON, A. G.; TREAGUST, D. F. Science analogies: avoid misconceptions with this sistematic approch. The Science Teacher, n. 61, p. 40-43, 1994.

HENRY, J. A revolução científica e as origens da ciência moderna. Rio de Janeiro: Jorge Zahar, 1998.

INEP. Exame Nacional de Cursos. Provão MEC, Física, 2002. Disponível em: $<$ http://www.inep.gov.br/superior/provao/gab_prov_pad_res/fisica.htm>. Acesso em: 12 mar. 2006.

ISABEL, C. A. P.; NAGEM, R, L. Analogias e metáforas e a mediação didática: uma relação possível? In: ENCONTRO NACIONAL DE DIDÁTICA E ENSINO, 11.,2002, Goiânia.

Resumos... Goiânia , 2002.

KNELLER, G. F. A ciência como atividade humana. Rio de Janeiro: Zahar/Edusp, 1987.

KOYRÉ, A. Do mundo fechado ao universo infinito. São Paulo: Editora da Universidade de São Paulo, 1979.

Estudos galilaicos. Lisboa: Publicações Dom Quixote, 1986. 
Melo, A. C. S.; Peduzzi, L. O. Q.

KUHN, T. S. A estrutura das revoluções científicas. São Paulo: Perspectiva, 1987.

LAKATOS, I. História da ciência e suas reconstruções racionais. Lisboa: Edições 70, 1998.

LANG, F. S. As premissas metafísicas da revolução copernicana. Caderno Brasileiro de Ensino de Física, Florianópolis, v. 19, n. 3, p. 407-410, 2002.

LOMBARDI, O. I. La pertinencia de la historia en la enseñanza de ciencias: argumentos y contraargumentos. Enseñanza de las ciencias, Barcelona, v. 15, n. 3, p. 343-349, 1997.

LOPES, A. R. C. Conhecimento escolar: quando as ciências se transformam em disciplinas. Rio de Janeiro, 1996a. Tese (Doutorado em Educação) - Universidade Federal do Rio de Janeiro.

Contribuições de Gaston Bachelard ao ensino de ciências. Caderno Catarinense do Ensino de Física, Florianópolis, v. 13, n. 3, p. 248-273, 1996b.

MARTINS, R. A. Como distorcer a Física: considerações sobre um exemplo de divulgação científica.1: física clássica. Caderno Catarinense de Ensino de Física, Florianópolis, v. 15, n. 3, p. 243-264, 1998.

MARTINS, R. A. Oersted e a descoberta do eletromagnetismo. Cadernos de História e Filosofia da Ciência, Campinas, v. 10, p. 115-122, 1986.

MATTHEWS, M. R. História, filosofia e ensino de ciências: a tendência atual de reaproximação. Caderno Catarinense do Ensino de Física, Florianópolis, n. 3, p. 164214, 1995.

MEDEIROS, A.; BEZERRA FILHO, S. A natureza da ciência e a instrumentação para o Ensino de Física. Ciência \& Educação, Bauru, v. 6, n. 2, p. 107-117, 2000.

MORAES, R. O que é esta coisa chamada ciência? Idéias sobre ciência de professores de Matemática, Física, Química e Biologia. In: ENCONTRO NACIONAL DE PESQUISA EM EDUCAÇÃO EM CIÊNCIAS, 4., 2003, Bauru. Anais... Bauru, 2003.

MORTIMER, E. F. Linguagem e formação de conceitos no ensino de ciência. Belo Horizonte: UFMG, 2000.

NASCIMENTO, V. B. A natureza do conhecimento científico e o ensino de ciências. In: CARVALHO, A. M. P. (Org.). Ensino de ciência: unindo a pesquisa e a prática. São Paulo: Pioneira Thomson Learning, 2004.

PEDUZZI, L. O. Q. Sobre a utilização didática da história da ciência. In: PIETROCOLA, M. (Org.). Ensino de Física: conteúdo, metodologia e epistemologia numa concepção integradora. Florianópolis: Editora da UFSC, 2001. p. 151-170.

Física atômica e filosofia: exemplares kuhnianos. Florianópolis: Departamento de Física/UFSC, 2004. (Publicação interna) 
Contribuições da Epistemologia Bachelardiana...

Do átomo grego ao átomo de Bohr. Florianópolis: Departamento de Física/ UFSC, 2005. (Publicação interna)

PEIXOTO, H. R. C.; MARCONDES, M. E. R. Reflexões sobre natureza da ciência em um curso de formação de professores. In: ENCONTRO NACIONAL DE PESQUISA EM EDUCAÇÃO EM CIÊNCIAS, 4., 2003, Bauru. Anais...? Bauru, 2003. p. 35.

PIETROCOLA, M. O. O éter luminoso como espaço absoluto. Cadernos de História e Filosofia da Ciência, São Paulo, v. 3, n. 1/2, p. 163-182, 1993.

PRAIA, J.; CACHAPUZ, A.; GIL-PÉREZ, D. A hipótese e a experiência científica em educação em ciência: contributos para uma reorientação epistemológica. Ciência \& Educação, Bauru, v. 8, n. 2, p. 253-262, 2002.

ROCHA, J. F. (Org.). Origens e evolução das idéias da Física. Salvador: EDUFBA, 2002.

SAMBURSKY, S. El mundo físico de los griegos. Madrid: Alianza Editorial, 1990.

SANTOS, M. E. V. M. Mudança conceitual na sala de aula: um desafio pedagógico. Lisboa: Livros Horizonte, 1991.

SILVA, A. V. P.; CALUZI, J. J.; NARDI, R.; et al. A História e a filosofia da ciência subsidiando a construção de atividades didáticas para o Ensino Médio de Física em nível médio. In: ENCONTRO DE PESQUISADORES EM ENSINO DE FÍSICA, 8., 2002, Águas de Lindóia. Anais... Águas de Lindóia, 2002.

SILVEIRA, M. P. Uma análise epistemológica do conceito de substância em livros didáticos de $5^{\text {a }}$ e $8^{\text {a }}$ séries do Ensino Fundamental. São Paulo, 2003. Dissertação (Mestrado em Educação) - Faculdade de Educação, Universidade de São Paulo.

STAUB, A. C. M.; PEDUZZI, L. O. Q. O papel da epistemologia em uma disciplina de evolução dos conceitos da Física. In: SIMPÓSIO NACIONAL DO ENSINO DE FÍSICA, 15., 2003a, Curitiba. Anais... Curitiba, 2003a.

.; __ Diálogo entre história e filosofia da ciência em uma disciplina de evolução dos conceitos da Física. In: ENCONTRO NACIONAL DE PESQUISA EM ENSINO DE CIÊNCIAS, 15., 2003b, Bauru. Anais... Bauru, 2003b.

.; __ A história da óptica à luz da epistemologia bachelardiana: um estudo exploratório. In: SIMPÓSIO NACIONAL DO ENSINO DE FÍSICA, 16., 2005, Rio de Janeiro. Anais... Rio de Janeiro, 2005.

TERRAZAN, E. A.; et al. Analogias no ensino de ciências: resultados e perspectivas. In: SEMINÁRIO DE PESQUISA EM EDUCAÇÃO DA REGIÃO SUL, 3., 2000, Porto Alegre. Anais... Porto Alegre, 2000.

THUILLIER, P. De Arquimedes a Einstein: a face oculta da invenção científica. Rio de Janeiro: Jorge Zahar, 1994. 
Melo, A. C. S.; Peduzzi, L. O. Q.

UTGES, G. R. Modelos e analogias na compreensão do conceito de onda. São Paulo, 1999. Tese (Doutorado em Educação) - Universidade de São Paulo.

VANNUCCHI, A. I. História e filosofia da ciência: da teoria para a sala de aula. São Paulo, 1996. Dissertação (Mestrado em Educação) - Faculdade de Educação, Universidade de São Paulo.

ZANETIC, J. Física também é cultura. São Paulo, 1989. Tese (Doutorado em Educação) - Universidade de São Paulo.

ZIMERMANN, E.; BERTANI, J. A. Um novo olhar sobre os cursos de formação de professores. Caderno Brasileiro de Ensino de Física, Florianópolis, v. 20, n. 1, p. 43-62, 2003.

Artigo recebido em outubro de 2006 e aceito em março de 2007. 